\title{
THE RESEARCH OF ORGANIC ACIDS IN BLACK ALDER (ALNUS GLUTINOSA (L.) GAERTN.) BUDS AND LEAVES
}

\author{
Yu.A.Fedchenkova, O.P.Khvorost \\ National University of Pharmacy \\ Key words: Alnus glutinosa; buds; leaves; organic acids
}

\begin{abstract}
By the means of the chromatography-mass-spectrometry method the comparative analysis of the qualitative composition and the quantitative content of organic acids in black alder buds and leaves have been carried out. Twelve organic acids have been identified in black alder buds, their total content is $1353.7 \mathrm{mg} / \mathrm{kg}$, and there are 11 organic acids in black alder leaves with the content twice as high as in buds $-3007.9 \mathrm{mg} / \mathrm{kg}$. One monocarboxylic, 6 dicarboxylic and 1 tricarboxylic, 4 aliphatic and aromatic organic acids have been found in buds. Two monocarboxylic, 5 dicarboxylic and 1 tricarboxylic, 5 aromatic organic acids have been found in leaves. The qualitative composition of organic acids is different in leaves and buds of black elder: 9 compounds have been found in both types of the plant material, namely capronic, oxalic, malonic, fumaric, succinic, malic, citric, vanillic and ferulic acids. Azelaic, benzoic and cinnamic acids have been found only in black alder buds, and black alder leaves contain only 2-hexenic and $\alpha$-hydroxyphenylpropionic acids. The dominating component in buds is citric acid $(625.8 \mathrm{mg} / \mathrm{kg})$, the lowest content has been detected for capronic $(10.3 \mathrm{mg} / \mathrm{kg})$ and fumaric $(4.5 \mathrm{mg} / \mathrm{kg})$ acids. The highest content in leaves has been detected for oxalic acid $(1403.9 \mathrm{mg} / \mathrm{kg})$, in small amounts fumaric and succinic $(8.3 \mathrm{mg} / \mathrm{kg}$ and $13.8 \mathrm{mg} / \mathrm{kg}$, respectively) acids are present in this plant material. The results obtained will be used in the further study of the black alder plant material.
\end{abstract}

A black alder - Alnus glutinosa (L.) Gaertn. from the birch (Betulaceae) family is a deciduous tree of the countries with a moderate climate. It grows on the coasts of the ponds, arm-holes of the rivers, swamps, often forms swamp forests [3]. The plant is officinal, the raw material (stem) is inscribed in the State Pharmacopeia USSR, edition XI [2]. The scientific medicine recommends the stem (cones) as an astringent, styptic, antimicrobial agent $[9,11]$. The Ukrainian pharmaceutical industry produces a gastroprotective and the antiulcer medicine "Altan" and a cardioprotective drug "Elgatsin" made of this raw material $[1,6]$. Buds and leaves of alder are applied by folk medicine as antimicrobic, astringent, styptic, antirheumatoid, antineoplastic agent in tumours of the breast, pancreas, stomach, esophagus, duodenum and rectum, throat, uterus [4]. The cytotoxic, antioxidant and antibacterial action of leaves is also known in literature $[5,7,8,10]$. The chemical composition of this plant is rather studied, but there is no detailed information about organic acids or comparative analysis of the content of these compounds in buds and leaves of black alder. Therefore, comparison of the qualitative composition of organic acids of buds and leaves of this plant, as well as comparison of the quantitative content of the components are relevant.

The aim of our research is comparative analysis of the qualitative composition and the quantitative content of organic acids in buds and leaves of black alder.

\section{Materials and Methods}

The objects of the research were buds (the swelling phase), leaves (the phase of full leaf expansion) collected in 2013 in Vilshansky district of the Kharkiv region from 10 trees of one bunch for more reliable comparison of results.

The research was performed by the method of chromatography-mass-spectrometry on an Agilent Technology $6890 \mathrm{~N}$ chromatograph with a mass-spectrometry detector $5973 \mathrm{~N}$. For this purpose the internal standard (the solution of $50 \mathrm{mkg}$ tridecane in hexane) and $1 \mathrm{ml}$ of the methyl agent $\left(14 \% \mathrm{BCl}_{3}\right.$ in methanol solution, Supelco 3-3033) was added to $50 \mathrm{mg}$ of a weighed quantity of the raw material in a $2 \mathrm{ml}$ vial. The mixture was kept in the hermetically closed vial for 8 hours at $65^{\circ} \mathrm{C}$. The plant material was filtered and the filtrate was diluted in $1 \mathrm{ml}$ of the distilled water. Methyl ethers were extracted in $0.2 \mathrm{ml}$ of chloride methylene shaken several times within an hour, then the extract obtained was chromatographed. The sample introduction $(2 \mathrm{mkl})$ to the chromatograph column was carried out in a splitless mode - without dividing the flow. The rate of the sample introduction was $1.2 \mathrm{ml} / \mathrm{min}$ for $0.2 \mathrm{~min}$.

The chromatograph column was capillary INNOWAX with the internal diameter of $0.25 \mathrm{~mm}$ and $30 \mathrm{~m}$ in length. The carrier gas velocity (helium) was $1.2 \mathrm{ml} / \mathrm{min}$. The temperature of the sample injection heater was $250^{\circ} \mathrm{C}$. The thermostat temperature was programmed from $50^{\circ} \mathrm{C}$ to $250^{\circ} \mathrm{C}$ with the rate of $4 \mathrm{deg} / \mathrm{min}$.

For identification of the components the data of the library of mass spectra of NIST05 and WILEY 2007 with the total number of spectra of more than 470000 were used with the help of the programme for AMDIS and NIST identification [12].

Results and Discussion

The results are given in Table. Twelve organic acids in buds and 11 ones in leaves have been found. 
Table

The qualitative composition and the quantitative content of organic acids in buds and leaves of black alder

\begin{tabular}{|c|l|c|c|}
\hline \multirow{2}{*}{$\begin{array}{c}\text { Retention } \\
\text { time, s }\end{array}$} & Name of a compound & $\begin{array}{c}\text { Quantitative } \\
\text { content, } \mathrm{mg} / \mathrm{kg}\end{array}$ \\
\cline { 3 - 4 } & buds & leaves \\
\hline \multicolumn{4}{|c|}{ Monocarboxylic aliphatic acids } \\
\hline 5.15 & caproic & 10.3 & 29.6 \\
\hline 7.14 & 2-hexenoic & - & 63.5 \\
\hline \multicolumn{4}{|c|}{ Dicarboxylic aliphatic acids } \\
\hline 9.82 & oxalic & 385.0 & 1403.9 \\
\hline 12.12 & malonic & 44.7 & 267.9 \\
\hline 12.87 & fumaric & 4.5 & 8.3 \\
\hline 13.98 & succinic & 12.4 & 13.8 \\
\hline 22.72 & malic & 60.2 & 266.8 \\
\hline 24.96 & azelaic & 37.9 & - \\
\hline \multicolumn{4}{|c|}{ Tricarboxylic aliphatic acids } \\
\hline 29.72 & citric & 625.8 & 620.9 \\
\hline \multicolumn{4}{|c|}{ Aromatic acids } \\
\hline 14.5 & benzoic & 15.7 & - \\
\hline 23.8 & cinnamic & 20.4 & - \\
\hline 27.71 & a-hydroxyphenylpropionic & - & 104.9 \\
\hline 32.83 & vanillic & 25.6 & 71.3 \\
\hline 40.69 & ferulic & 111.2 & 157.0 \\
\hline Total & 1353.7 & 3007.9 \\
\hline
\end{tabular}

Azelaic, benzoic and cinnamic acids have been found only in black alder buds, and black alder leaves contain only 2 -hexenic and $\alpha$-hydroxyphenylpropionic acids.

The total content of organic acids in buds was $1353.7 \mathrm{mg} / \mathrm{kg}$, in leaves twice as high $-3007.9 \mathrm{mg} / \mathrm{kg}$. In buds citric acid $(625.8 \mathrm{mg} / \mathrm{kg})$ was in the highest content, which was comparable with the content of this compound in leaves $(620.9 \mathrm{mg} / \mathrm{kg})$. In leaves the highest content was determined for oxalic acid $-1403.9 \mathrm{mg} / \mathrm{kg}$, it was more than 3.5 times higher the content of this acid in buds. It can be associated with accumulation of crystals and druses of calcium oxalate in leaves.
The content of dicarboxylic malonic and malic acids in buds was $44.7 \mathrm{mg} / \mathrm{kg}$ and $60.2 \mathrm{mg} / \mathrm{kg}$, respectively. In leaves the content of these acids increased six times and more than four times and was $267.9 \mathrm{mg} / \mathrm{kg}$ and $266.8 \mathrm{mg} / \mathrm{kg}$, respectively. Besides, the ring A of the molecules of flavonoids is synthesized from 3 active molecules of malonic acid.

There were $4.5 \mathrm{mg} / \mathrm{kg}$ of fumaric acid in buds and $8.3 \mathrm{mg} / \mathrm{kg}$ in leaves. This compound is found in the plants of Fumaraceae, Papaveraceae family, in some lichens and fungi; it is an intermediate product in the synthesis of asparagenic acid.

There were $111.2 \mathrm{mg} / \mathrm{kg}$ of hydroxicinnamic acid pherulic acid in buds and $157.0 \mathrm{mg} / \mathrm{kg}$ in leaves. This compound is an effective antioxidant, antitumoral agent, has the stress-protective action, reducing lesions of the gastric mucosa and myocardial damage caused by the immobilization-pain stress. It is caused most likely by the ability of pherulic acid to inhibit the processes of lipid peroxidation and to strengthen oxidant processes in the cardiac muscle.

Thus, buds of black alder contained $39.7 \mathrm{mg} / \mathrm{kg}$ of azelaic acid known as a keratolytic, antibacterial and antiinflammatory agent. In the plants azeloinic acid is 'a flash distress', which takes part in defense reactions after infection. Under the effect of this compound the accumulation of salicylic acid - an important component of the defense reaction of plants begins. Azelaic acid is contained in the plants of Poaceae family. Medicines containing azelaic acid are active in relation to Propionibacterium acnes, Staphylococcus epidermidis, Staphylococcus aureus, Streptococcus, etc.

The results obtained will be used in the further study of the black alder plant material.

\section{CONCLUSIONS}

1. Twelve organic acids have been identified in black alder buds, and there are 11 mono-, di-, tri- carboxylic aliphatic and aromatic organic acids in black alder leaves.

2. The qualitative composition of organic acids is different, 9 compounds have been found in both types of the plant material.

3. The dominating component in buds is citric acid $(625.8 \mathrm{mg} / \mathrm{kg})$, in leaves it is oxalic acid $(1403.9 \mathrm{mg} / \mathrm{kg})$.

\section{REFERENCES}

1. Великоданов Г.Л., Шевелева Н.Е., Дика О.М. // Клінічна фармація. - 2003. - T. 7, №2. - С. 51-54.

2. Государственная фармакопея СССР. Вып. 2. Общие методы анализа / МЗ СССР. - 11-е изд., доп. - М.: Медииина, 1989. - С. 279

3. Дикорастущие полезные растения России / Отв. ред. А.Л.Буданцев, Е.Е.Лесиовская. - Изд-во СПХФА, 2001. - C. 139-141.

4. Травник. Ольха клейкая [Электронный ресурс]: информация о том, как полностью себя излечить, оздоровиться, восстановить жизненную энергию, бросить вредные привычки и многое другое. Ваше здоровье без таблеток и операиий. Я здоров! Режим достуnа: http://www.ayzdorov.ru/. Загл. с экрана.

5. Фитопрепараты и биологически активные вещества лекарственных растений в комплексной терапии злокачественных новообразований (экспериментальное исследование): Автореф. дис. ... докт. биол. наук / Т.Г.Разина. - Томск: НИИ фармакол. Томск. науч. иентра СО РАМН, 2006.

6. Яковлева Л.В., Карбушева І.В., Лар'яновська Ю.Б. // Фармаком. - 2004. - №3. - С. 36-41.

7. Lai Y.C., Chen C.K., Lee S.S. // Planta Med. - 2009. - Vol. 75. - P. 50. 
8. Middletona P., Stewarta S., Al-Qahtania F. et al. // Iranian J. of Pharmac. Res. - Vol. 4, №2. - P. 101-103.

9. Mushkina O., Gurina N., Konopleva M. et al. // Acta Sci. Pol., Hortorum Cultus. - 2013. - Vol. 12, №3. - P. 3-11.

10. Novaković M., Stanković M., Vučković I. et al. // Planta Med. - 2013. - Vol. 79, №6. - P. 499-505.

11. Sushil Chandra S., Nitin S., Sati O.P. // Pharmacogn. Rev. - 2011. - Vol. 5, №10. - P. 174-183.

12. Sychov C.S., Ilyin M.M., Davankov V.A., Sochilina K.O. // J. Chromatogr. A. - 2004. - №1. - P. 17-24.

ДОСЛІДЖЕННЯ ОРГАНІЧНИХ КИСЛОТ БРУНЬОК ТА ЛИСТЯ ВІЛЬХИ КЛЕЙКОЇ ALNUS GLUTINOSA (L.) GAERTN.

Ю.А.Федченкова, О.П.Хворост

Ключові слова: вільха клейка; бруньки; листя; органічні кислоти

За допомогою методу хромато-мас-спектрометрії проведений порівняльний аналіз якісного складу та кількісного вмісту органічних кислот у бруньках та листі вільхи клейкої. В бруньках вільхи клейкої ідентифріковано 12 органічних кислот, загальний вміст яких становив 1353,7 мг/ка, а в листі - 11 органічних кислот із загальним вмістом вдвічі вищим, ніж у бруньках - 3007,9 мг/ке. У бруньках знайдено 1 монокарбонову кислоту, 6 дикарбонових кислот та 1 трикарбонову, 4 аліфратичні та ароматичні органічні кислоти. В листі знайдено 2 монокарбонові кислоти, 5 дикарбонових кислот та 1 трикарбонову, 5 ароматичних органічних кислот. Якісний склад органічних кислот у бруньках та листі вільхи клейкої різнився, 9 сполук знайдено в обох видах сировини, а саме капронову, щавлеву, малонову, фумарову, янтарну, яблучну, лимону, ванілінову, фрерулову органічні кислоти. Азелаїнова, бензойна, корична кислоти містилися тільки в бруньках вільхи клейкої, а 2-гексенова та а-оксифренілпропіонова - тільки в листі вільхи клейкої. Домінуючим компонентом бруньок була лимонна кислота (625,8 мг/кг), найнижчий вміст визначено для капронової (10,3 мг/кг) та фрумарової (4,5 мг/кг) кислот. У листі спостерігався найвищий вміст щавлевої кислоти (1403,9 мг/ка), в незначних кількостях в цьому виді сировини містилися фрумарова та янтарна кислоти (8,3 мг/ка та 13,8 мг/ка відповідно). Отримані результати будуть використані в подальших дослідженнях сировини вільхи клейкої.

\section{ИССЛЕДОВАНИЕ ОРГАНИЧЕСКИХ КИСЛОТ В ПОЧКАХ И ЛИСТЬЯХ ОЛЬХИ КЛЕЙКОЙ ALNUS GLUTINOSA (L.) GAERTN. \\ Ю.А.Федченкова, О.П.Хворост \\ Ключевые слова: ольха клейкая; почки; листья; органические кислоты}

С помощью метода хромато-масс-спектрометрии проведен сравнительный анализ качественного состава и количественного содержания органических кислот в почках и листьях ольхи клейкой. В почках ольхи клейкой идентифицировано 12 органических кислот, общее содержание которых составило 1353,7 м2/ка, а в листьях - 11 органических кислот с общим содержанием, вдвое большим, чем в почках - 3007,9 мг/ке. В почках обнаружено 1 монокарбоновую кислоту, 6 дикарбоновых кислот, 1 трикарбоновую, 4 алифатические и ароматические органические кислоты. В листьях найдены 2 монокарбоновые кислоты, 5 дикарбоновых кислот и 1 трикарбоновая, 5 ароматических органических кислот. Качественный состав органических кислот в почках и листьях ольхи клейкой отличался, 9 соединений найдены в обоих видах сырья, а именно капроновая, щавелевая, малоновая, фумаровая, янтарная, яблочная, лимонная, ванилиновая, фреруловая органические кислоты. Азелаиновая, бензойная и коричная кислоты содержались только в почках ольхи клейкой, а 2-гексеновая и $\alpha$-оксифенилпропионовая - только в листьях ольхи клейкой. Доминирующим компонентом почек является лимонная кислота (625,8 м2/к2), низкое содержание определили у капроновой (10,3 мг/ка) и фрумаровой (4,5 мг/ка) кислот. В листьях наблюдалось высокое содержание щавелевой кислоты (1403,9 ма/к2), в незначительных количествах в этом виде сырья содержались ффумаровая и янтарная кислоты (8,3 мг/ке и 13,8 мг/ка соответственно). Полученные результаты будут использованы в дальнейших исследованиях сырья ольхи клейкой. 